\title{
The versatility of the Moringa oleifera oil in sustainable applications
}

\author{
Francisco S.G. Pereira ${ }^{1, \star}$, Chesque C. Galvão ${ }^{2}$, Valmir F. de Lima ${ }^{2}$, Márcia F.A. da Rocha ${ }^{2}$, \\ Alexandre R.P. Schuler ${ }^{2}$, Valdinete L. da Silva ${ }^{2}$ and Nelson M. de Lima Filho ${ }^{2}$ \\ ${ }^{1}$ Federal Institute of Education, Science and Technology of Pernambuco - IFPE. Campi Recife and Ipojuca, Recife, PE, Brazil \\ ${ }^{2}$ Federal University of Pernambuco - UFPE, Center of Technology and Geosciences. Department of Chemical Engineering. Recife, PE, Brazil
}

Received 31 January 2016 - Accepted 30 May 2016

\begin{abstract}
This study had as aims the extraction, purification and characterization of moringa oil for everyday applications with backing scientific. The average oil yield was of $23.92 \%$, using the techniques: mechanical pressing $(11.36 \%)$ and by with hexane extraction $(35.48 \%)$. The oil extracted by pressing was analysed for gas chromatography, revealing a profile of $21.5 \%$ of saturated fatty acids and $78.5 \%$ of unsaturated fatty acids, having the oleic acid as the major component. The mixed crude oil was refined in four steps: degumming, neutralization, washing and drying. The crude and refined oils were characterised through their acidity index $\left(8.8 ; 20.5\right.$ and $\left.0.2 \mathrm{mg}_{\mathrm{KOH}} \mathrm{g}^{-1}\right)$, peroxide index (3.3; $5.4 \mathrm{meqO}_{2} \mathrm{~kg}^{-1}$ and not detected), water content (876.6; 632.0 and $630.2 \mathrm{mg} \mathrm{kg}^{-1}$ ), turbidity $(64.1 ; 12.6$ and 2.1 NTU), specific mass $\left(909.5 ; 907.2\right.$ and $\left.907.0 \mathrm{~kg} \mathrm{~m}^{3}\right)$, kinematic viscosity $\left(43.6 ; 39.1\right.$ and $\left.41.7 \mathrm{~mm}^{2} \mathrm{~s}^{-1}\right)$, high power calorific (39.7; 40. and 39.4 $\left.\mathrm{MJ} \mathrm{kg}^{-1}\right)$ and calorific value lower $\left(36.9 ; 36.9 ; 37.1 \mathrm{MJ} \mathrm{kg}^{-1}\right)$, and ash content $(0.05 ; 0.05$ and $0.007 \%$ ), respectively. The results show that moringa is a viable and sustainable plant in the use of its oil as raw material for several industries, especially in the food, cosmetic, pharmaceutical and biodiesel industry.
\end{abstract}

Keywords: Oil analysis / oil extraction / turbidity in oil / energy in oil / moringa oil

\begin{abstract}
Résumé - Polyvalence de l'huile de Moringa oleifera dans des applications durables. Cette étude avait comme objectif l'extraction, la purification et la caractérisation de l'huile de moringa pour des applications quotidiennes. Le rendement moyen de l'huile était de $23,92 \%$, en utilisant les techniques suivantes : pressage mécanique $(11,36 \%)$ et extraction à l'hexane $(35,48 \%)$. L'huile extraite par pressage a été analysée par chromatographie en phase gazeuse, révélant un profil de 21,5\% d'acides gras saturés et 78,5\% d'acides gras insaturés, l'acide oléique étant le composant principal. L'huile brute mixte (mélange des huiles extraites par pression et solvant, proportion 1:4) a été raffinée en quatre étapes : dégommage, neutralisation, lavage et de séchage. Les huiles brutes (pressage ou solvant) et l'huile raffinée ont été caractérisées par leur indice d'acidité $\left(8,8 ; 20,5\right.$ et $\left.0,2 \mathrm{mg}_{\mathrm{KOH}} \mathrm{g}^{-1}\right)$, leur indice de peroxyde $(3,3$; $5,4 \mathrm{meqO}_{2} \mathrm{~kg}^{-1}$ et non détectée), leur teneur en eau $\left(876,6 ; 632,0\right.$ et $\left.630,2 \mathrm{mg} \mathrm{kg}^{-1}\right)$, leur turbidité $(64,1 ; 12,6$ et 2,1 NTU), leur masse spécifique $\left(909,5 ; 907,2\right.$ et $\left.907,0 \mathrm{~kg} \mathrm{~m}^{-3}\right)$, leur viscosité cinématique $\left(43,6 ; 39,1\right.$ et $\left.41,7 \mathrm{~mm}^{2} \mathrm{~s}^{-1}\right)$, leur pouvoir calorifique supérieur $\left(39,7 ; 40,0\right.$ et $\left.39,4 \mathrm{MJ} \mathrm{kg}^{-1}\right)$ et inférieur $\left(36,9 ; 36,9 ; 37,1 \mathrm{MJ} \mathrm{kg}^{-1}\right)$, et leur teneur en cendres $(0,05 ; 0,05$ et 0,007 Les résultats montrent que moringa est une plante viable et durable dans l'utilisation de son huile comme matière première pour plusieurs industries, en particulier dans l'industrie alimentaire, cosmétique, pharmaceutique et le biodiesel.
\end{abstract}

Mots clés : Analyse / extraction / turbidité / énergie / huile de moringa

\section{Introduction}

The origin of Moringa oleifera Lamarck is mentioned as a culture that dates from ancient times, coming from Agra and Oudh in India, south of the Himalayas (Foidl et al., 2001);

^ Correspondence: cientista.francisco@yahoo.com.br belonging to the Moringaceae family, of single genus, being one of the 13 species (Fahey, 2005). Its cultivation can be done in arid, semiarid and warm areas, with temperatures varying between 25 and $35^{\circ} \mathrm{C}$, being able to tolerate until $48{ }^{\circ} \mathrm{C}$ and in weak frost conditions in subtropical areas (HDRA, 2002). It is tolerable to drought and grows with annual precipitation 


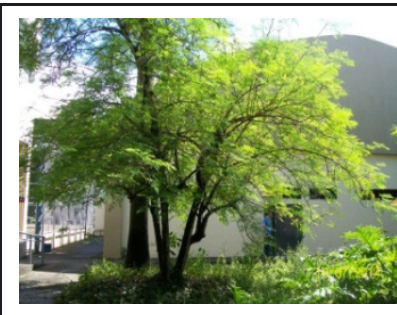

(a)

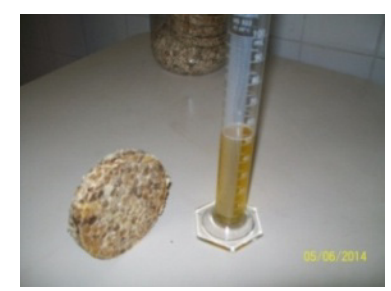

(d)

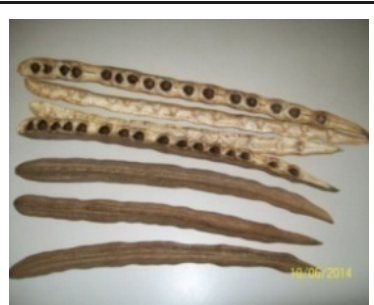

(b)

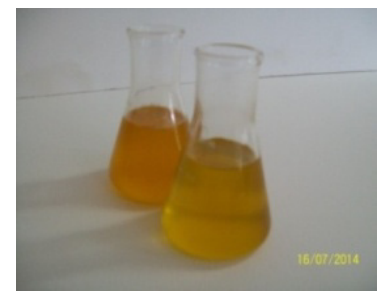

(e)

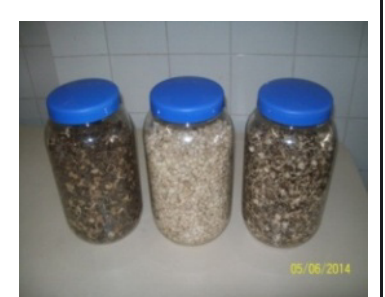

(c)

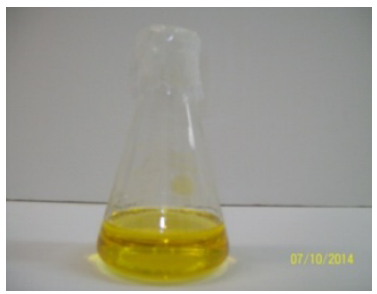

(f)

Fig. 1. Plant and some biomasses obtained from moringa. (a) One of the trees used in the collection (Etepam, Encruzilhada, Recife, Brazil, 2014). (b) seed pods opened and closed (30 to $40 \mathrm{~cm} /$ average of 16 seeds per pod). (c) seeds, grains (white) and seed husks. (d) cake (or pie) of the mechanical pressing from the grains (seed without husks). (e) pressing oil (front) and extraction oil with hexane (background). (f) mixed purified oil.

between 250 and $3000 \mathrm{~mm}$ in altitudes under $600 \mathrm{~m}$. Furthermore, it evolves in soil with $\mathrm{pH}$ varying from 5.0 to 9.0 , but it prefers neutral and well-drained soils. It also adapts better in sandy-clay, well-drained soil and it can grow in clay soil without standing water. It does not require soil fertility, developing itself in poor soil as well, starting to flower 8 months after being planted (Crosby, 2007). The production rates of a tree are verified within 3 years of being planted, being able to produce between 1000-1600 seed pods per year with an average of 24000 seeds. The seed pod frequently coming from the canopies is capable of maintaining and increasing the growth of the leaves and the height control to simplify the seedpods harvesting (HDRA, 2002).

Moringa oleifera (Fig. 1a) is cultivated due to its nutritional value (leaves, green fruits, flowers and roasted seeds); its forage value (leaves, fruits and seeds); its medicinal value (all parts of the plant); its condimental (mainly the roots) and culinary value; its importance to the cosmetic industry (oil extracted from the seeds); its pollen (the flowers); its importance for fuel (wood and oil) and in the water treatment for human consumption (cotyledons and seed teguments) (Crosby, 2007; Jahn, 1989; Morton, 1991).

Oils and fats are presented as substances gathered into two categories: glycerides and non-glycerides. The glycerides are produced by the esterification of a glycerol molecule with up to three fatty acid molecules (mono, di and triacylglycerols). The non-glycerides are found in small quantities (5\% in crude oleaginous and $2 \%$ in the refined) such as phosphatides (lectins, cefalins, phosphatidylinositol); sterols (stigmasterol); waxes (cetyl palmitate); insoluble hydrocarbons (squalene); carotenoids; chlorophyll; tocopherols (vitamin E); lactones and methyl-ketone. Those still present in the refined oil, even in small quantity, can change their characteristics due to a peculiar property, as for example a pro or anti-oxidant action, be strongly odoriferous, of concentrated flavour or be highly coloured. The triacylglycerols or triglycerides are insoluble compounds in water and in room temperature have liquid or solid consistency. When in its solid form they are called fat, and under its liquid form, oil. Besides the triacylglycerols, the oils contain various components in smaller scale, such as mono and diglycerides (important as emulsifiers); free fatty acids; tocopherol (important antioxidant); proteins, sterols and vitamins (Reda and Carneiro, 2007).

Due to the versatility of vegetable oils in ordinary applications, this study investigated the oil of the moringa seeds, determining some of their physicochemical properties and the basic structural composition in fatty acids.

\section{Material and methods}

\subsection{Moringa oil extraction by mechanical pressing and by solvent extraction}

The oil extraction was preceded by the processing of the moringa seedpods collected between April and May 2014 in Recife, State of Pernambuco, Brazil. The cleaned and suitable pods (Fig. 1b) were separated in pods husks and seeds that generated the grains (seed without husks) and new husks (Fig. 1c). The grains were then converted into cakes (or pies) and crude oil (Fig. 1d).

The oil was extracted by mechanical pressing (200 $\mathrm{g}$ of grains per test/heating in greenhouse for $2 \mathrm{~h}$ at $105^{\circ} \mathrm{C} /$ and pression of 10 tons $\left(412.5 \mathrm{~kg} \mathrm{~cm}^{-2}\right)$ for $5 \mathrm{~min}$. and with hexane solvent in Soxhlet equipment (200 g per test / crushed and sieved in 100 mesh or $0.149 \mathrm{~mm}$ opening / transferred to cartridge extractor/used approximately $700 \mathrm{ml}$ of hexane P.A. (Modern Chemistry) by operation/refluxed for extraction for $4 \mathrm{~h}$ /distillation of the mixture (oil + hexane) for separation of the components/use of the rotary evaporator (Fisatom 
Brazil, mod. 801) at $110{ }^{\circ} \mathrm{C}$ for $2 \mathrm{~h}$ in thermostatic bath with ethyleneglycol for waste solvent disposal and to remove possible volatile impurities in the crude oil/desolventization at $105{ }^{\circ} \mathrm{C}$ in greenhouse for $2 \mathrm{~h} /$ cooling in desiccator and weighing).

The cakes (or pies) produced by mechanical pressing were crushed in laboratory blender, sieved (100 mesh) and had their residual oil extracted in similar procedure to the grains. The extracted oils (Fig. 1e) have presented a slightly different odour and colour and were stored in amber bottles to avoid photolytic degradation and in laboratory temperature (around $20{ }^{\circ} \mathrm{C}$ ) during the analysis. The mixed crude oil (by pressing and by solvent extraction, 1:4 proportion) was degummed ( $20 \%$ of deionized water in relation to the oil/temperature of $60{ }^{\circ} \mathrm{C}$ in thermostatically-controlled water bath / $500 \mathrm{rpm}$ for $15 \mathrm{~min} /$ centrifugation at $5000 \mathrm{rpm}$ for $15 \mathrm{~min}$ ), 3 times washed (deionized water / treated oil in 1:1 proportion/ agitation of $1000 \mathrm{rpm}$ for $30 \mathrm{mins}$. / decantation for $2 \mathrm{~h}$ ) and dried (heated to $100{ }^{\circ} \mathrm{C}$ for $60 \mathrm{~min}$. with intermittent agitation every 5 mins.), and converted in purified oil (Fig. 1f).

\subsection{Chromatographic characterisation of the extracted moringa oils}

The moringa oil obtained by mechanical pressing was analysed through the conversion of your presents fatty acids in methylic esters (FAMEs) according to Hartman and Lago (1973), adapted to microscale, followed by gas chromatographic analysis with an FID detector.

Afterwards, in a autoclavable tube of $20 \mathrm{ml}$ was weighed approximately $35.0 \mathrm{mg}$ of moringa oil and $3.0 \mathrm{ml}$ of solution $0.5 \mathrm{~mol} \mathrm{~L}^{-1}$ of sodium hydroxide $\left(\right.$ Merck $\left.^{\circledR}\right)$ in dry methanol (Tedia ${ }^{\circledR}$ ) and heated in water bath for $10 \mathrm{~min}$ at $90{ }^{\circ} \mathrm{C}$. The tube was cooled in an ice bath and $9.0 \mathrm{ml}$ was added of the esterification mixture and heated for $10 \mathrm{~min}$. in a water bath at $90{ }^{\circ} \mathrm{C}$. The tube was then cooled in ice bath and $5.0 \mathrm{ml}$ of $\mathrm{n}$ heptane $\left(\right.$ Tedia $\left.^{\circledR}\right)$ and $2.0 \mathrm{ml}$ of distilled water were added. This mixture was vigorously agitated and left at rest until phase separation. The heptanic phase was collected with a Pasteur pipette and analysed with gas chromatography.

For the analysis of the composition of the FAMEs and to calculate the level of ester, a gas chromatograph Agilent 7890 was used, with an FID detector and split/splitless injector; the capillary column used was the DB-WAX $(30 \mathrm{~m} \times 0.25 \mathrm{~mm} \times$ $0.25 \mu \mathrm{m})$. The stove was operated under the initial temperature of $70{ }^{\circ} \mathrm{C}$, being heated at $10{ }^{\circ} \mathrm{C} / \mathrm{min}$ until $240{ }^{\circ} \mathrm{C}$, and maintained at this temperature for $13 \mathrm{~min}$, and once again heated at $5{ }^{\circ} \mathrm{C} \min ^{-1}$ until $250{ }^{\circ} \mathrm{C}$. The injector was kept at $310^{\circ} \mathrm{C}$ with an injection volume of $2 \mu$ l, on split mode, with Hydrogen 5.0 being used as a carrier gas at a linear speed of $42 \mathrm{~cm} \mathrm{~s}^{-1}$ with Nitrogen 5.0 being used as an auxiliary gas at $20 \mathrm{ml} \mathrm{min}^{-1}$. The FAMEs were identified by direct comparison with samples of known composition such as soybean, peanut and crambe oil, reference FAMEs standards (Nu-Check Prep ${ }^{\circledR}$ ) and by analysis via high resolution gas chromatography attached to mass spectrometry (GC-MS) (gas chromatography Shimadzu 17A attached to mass spectrometry QP-5050 Shimadzy, interface at $280{ }^{\circ} \mathrm{C}$, helium 5.0 as carrier gas, linear speed of $42 \mathrm{~cm} \mathrm{~s}^{-1}$, stove conditions, injector and capillary column at $280^{\circ} \mathrm{C}$ ).

\subsection{Physicochemical characterization of the extracted and purified moringa oils}

The oils were characterized through their acidity index, peroxide index, saponification index and iodine value (Physicochemical Methods for Food Analysis of the Adolfo Lutz Institute - IAL, IV Edition, 1st Digital, 2008), specific mass (NBR 14065/ASTM D4063 and NB 7148), kinematic viscosity (NBR 10441/ASTM D445), water content for Karl Fischer (NBR 11348/ASTM D6304), turbidity (standard operational procedure of the turbidimeter $\mathrm{HACH} 2100 \mathrm{~N}$ ), high power calorific (standard operational procedure of the calorimeter IKA C 200), lower calorific value (calculated based on the high power calorific and water content of the sample) and ash content (NBR 9842 from ABNT).

\section{Results and discussion}

\subsection{Chromatographic parameters of the pressing oil esterified}

In the evaluation of the data obtained for methylic esters (FAMEs) of the moringa oil obtained by mechanic pressing and esterified by the Hartman and Lago (1973) method and through the profile of the fatty acids (Fig. 2), comparing to some researches (Abdulkarim et al., 2005; Compaoré et al., 2011; Lalas and Tsaknis, 2002; Rashid et al., 2008; Santana et al., 2010; Tsaknis et al., 1999), an international convergence of these components was observed, prevailing the highest percentage of the unsaturated fatty acids over the saturated, with emphasis to the oleic acid (monounsaturated with 18 carbon atoms and cis configuration, varying between 67.9 and $78.0 \%$ ).

The high level of oleic acid (Tab. 1) in the moringa oil structure provides a good fluidity as well as a low viscosity and makes it less likely in rancidification or oxidative deterioration due to the only double bond of this fatty acid (Pereira, 2015). The study verified a $70.2 \%$ of oleic acid and $4.6 \%$ of its positional isomer, the vaccenic acid, having a total of $74.8 \%$ of monounsaturated $\mathrm{C} 18$, matching the data obtained. For the saturated fatty acids, the biographies mentioned data varying from 19.0 to $27.0 \%$, and this study verified $21.5 \%$. Even with distinctive and global proveniences, there was a certain convergence in the fatty profile for the moringa oil, it being adequate for biodiesel production or others applications such as in feed, medicinal or cosmetic.

\subsection{Physicochemical parameters of the extracted moringa oils}

The parameters chosen (Tab. 2) were with intention to evaluate the degradation or stability of the post-extraction oil, storage and conservation (acidity index, peroxide index and water content) and for the general comparative characteristics of vegetable oils (specific mass, kinematic viscosity, saponification index and iodine value). The turbidity was chosen to evaluate the presence of colloidal impurities interfering, mainly phosphatides and other colloids; the water and ash contents to evaluate the energetic potential of these biomasses for direct or indirect use (Pereira, 2015). 


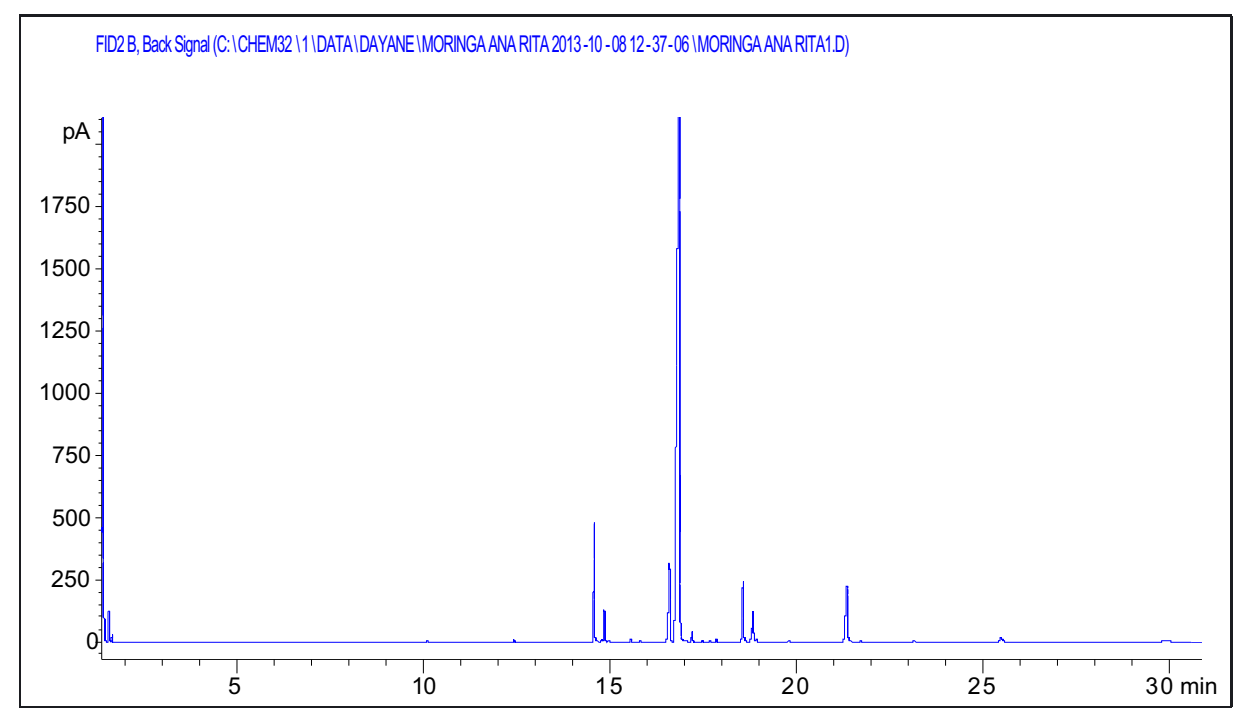

Fig. 2. Chromatogram obtained from the Moringa oleifera oil.

Table 1. Profile of the fatty acids of the moringa oil by mechanical pressing and esterified.

\begin{tabular}{cccccc}
\hline $\begin{array}{c}\text { Retention } \\
\text { time (mins.) }\end{array}$ & $\begin{array}{c}\text { Fatty acid } \\
\text { symbol }\end{array}$ & $\begin{array}{c}\text { Methyl ester of the } \\
\text { fatty acid }\end{array}$ & $\begin{array}{c}\text { Tachygraphic } \\
\text { notation }\end{array}$ & $\begin{array}{c}\text { Content } \\
(\%)\end{array}$ & Types of fatty acids (\%) \\
\hline 12.4 & $\mathrm{M}$ & Myristic & $\mathrm{C} 14: 0$ & 0.2 & Saturated Fatty Acids (SFA) - 21.5 \\
14.5 & $\mathrm{P}$ & Palmitic & $\mathrm{C} 16: 0$ & 5.8 & \\
14.8 & $\mathrm{Po}$ & Palmitoleic & $\mathrm{C} 16: 1 c 9$ & 1.4 & Monounsaturated Fatty Acids (MUFAs) - 78.1 \\
16.6 & $\mathrm{~S}$ & Stearic & $\mathrm{C} 18: 0$ & 6.2 & \\
16.7 & $\mathrm{O}$ & Oleic & $\mathrm{C} 18: 1 c 9$ & 70.2 & Di-unsaturated Fatty Acids (DUFAs) -0.4 \\
16.8 & $\mathrm{~V}$ & Vaccenic & $\mathrm{C} 18: 1 c 11$ & 4.6 & \\
17.2 & $\mathrm{~L}$ & Linoleic & $\mathrm{C} 18: 2 c 9,12$ & 0.4 & Tri-unsaturated Fatty Acids (TUFAs) -0.0 \\
18.5 & $\mathrm{~A}$ & Arachidonic & $\mathrm{C} 20: 0$ & 3.7 & \\
18.8 & $\mathrm{Ga}$ & Gadoleic & $\mathrm{C} 20: 1 c 11$ & 1.9 & Polyunsaturated Fatty Acids (PUFAs) -0.0 \\
21.2 & $\mathrm{Be}$ & Behenic & $\mathrm{C} 22: 0$ & 5.6 & \\
\hline
\end{tabular}

Table 2. Analytical parameters for the moringa oils investigated.

\begin{tabular}{|c|c|c|c|c|}
\hline \multirow[b]{2}{*}{ Analytical parameters measured } & \multicolumn{4}{|c|}{ Samples investigated } \\
\hline & $\begin{array}{c}\text { Grain oil by } \\
\text { mechanical } \\
\text { pressing }\end{array}$ & $\begin{array}{c}\text { Grain oil by } \\
\text { solvent } \\
\text { extraction }\end{array}$ & $\begin{array}{c}\text { Mixed crude } \\
\text { oil }\end{array}$ & $\begin{array}{c}\text { Mixed } \\
\text { purified oil }\end{array}$ \\
\hline Acidity index (mg $\mathrm{KOH} \mathrm{g}^{-1}$ oil) (IAL-2008) & 8.8 & 20.5 & 18.1 & 0.2 \\
\hline Peroxide index $\left(\mathrm{meqO}_{2} \mathrm{~kg}^{-1}\right.$ of oil $)(\mathrm{IAL}-2008)$ & 3.3 & 5.4 & 5.2 & n.d. $(* *)$ \\
\hline Water content (Karl Fischer) $\left(\mathrm{mg} \mathrm{kg}^{-1}\right)$ (NBR 11348/ASTM D6304) & 876.6 & 632.0 & - & 630.2 \\
\hline Specific mass $\left(\mathrm{kg} \mathrm{m}^{-3}\right.$ at $\left.20^{\circ} \mathrm{C}\right)(\mathrm{NBR} 14065 / \mathrm{ASTM} \mathrm{D} 4052)$ & 909.5 & 907.2 & - & $907.0(*)$ \\
\hline Kinematic Viscosity $\left(\mathrm{mm}^{2} \mathrm{~s}^{-1}\right.$ at $\left.40^{\circ} \mathrm{C}\right)(\mathrm{NBR} 10441 / \mathrm{ASTM}$ D445) & 43.6 & 39.1 & - & 41.7 \\
\hline Saponification index $\left(\mathrm{mg}_{\mathrm{KOH}} \mathrm{g}^{-1}\right.$ of oil) (IAL-2008) & 180.6 & 179.4 & - & - \\
\hline Iodine value $\left(\mathrm{gI}_{2} 100 \mathrm{~g}^{-1}\right.$ of oil) (Wijs / IAL-2008) & 68.9 & 70.7 & - & - \\
\hline Turbidity (NTU at $20^{\circ} \mathrm{C}$ ) (Turbidimeter Hach $2100 \mathrm{~N}$ ) & 64.1 & 12.6 & 18.7 & 2.1 \\
\hline Higher calorific value (HCV) $\mathrm{MJ} \mathrm{kg}^{-1}$ (IKA C2000) & 39.7 & 40. & - & 39.4 \\
\hline Lower calorific value (LCV) $\mathrm{MJ} \mathrm{kg}^{-1}$ (Calculated) & 36.7 & 36.9 & - & 37.1 \\
\hline Ash content $(\%)($ NBR 9842) & 0.05 & 0.05 & - & 0.007 \\
\hline
\end{tabular}

(*) obtained by the densimeter method NBR 7148; (**) n.d. - not detected with the analytical method used. 
The acidity index measures the presence of free fatty acids (FFAs) generated by effects of the hydrolysis or oxidative and were considered high for crude oils (pressing, by solvent extraction and mixed oil), but the mixed purified (degummed, neutralised, washed and dried) presented acceptable conditions for various uses (Pereira, 2015). Reference studies for the moringa oil presented strong variation of this index, from $0.33 \mathrm{mg}_{\mathrm{KOH}} \mathrm{g}^{-1}$ of oil (Pereira et al., (2010, by pressing) until $5.89 \mathrm{mg}_{\mathrm{KOH}} \mathrm{g}^{-1}$ of oil (Santana et al., 2010, by solvent), demonstrating that the extractive method by solvent has a negative influence in the quality of the oil, explained by the heating and chemical interactions between the substances (oil and solvent) and confirmed with the results (Tab. 2) obtained in this study of $8.8 \mathrm{mg}_{\mathrm{KOH}} \mathrm{g}^{-1}$ for mechanical pressing oil and of $20.5 \mathrm{mg}_{\mathrm{KOH}} \mathrm{g}^{-1}$ for the oil extracted by hexane. The conditions of production and storage of the seeds, the expiration date, time of processing and ways of manipulation favour the increase of this index (negative aspect). The mixed moringa crude oil presented $18.1 \mathrm{mg}_{\mathrm{KOH}} \mathrm{g}^{-1}$, value much above $4 \mathrm{mg}_{\mathrm{KOH}} \mathrm{g}^{-1}$ (crude) or $0.6 \mathrm{mg}_{\mathrm{KOH}} \mathrm{g}^{-1}$ (refined oils) indicated by the RDC 270/2005 - ANVISA, acceptable conditions for direct food or cosmetic, or treaty for the biodiesel production. Degumming, neutralisation, washing and drying modified acidity index the oil after the purification for $0.2 \mathrm{mg}_{\mathrm{KOH}} \mathrm{g}^{-1}$ of oil (mixed moringa oil purified) (Pereira, 2015).

The peroxide index is associated to the oxidation reactions due to the oxygen's effect in the double bonds of the fatty acids present in the oil and intrinsically linked to the increase in the acidity index and vice-versa. The values of this study (Tab. 2) were of 3.3, 5.4 and 5.2 meqO $_{2} \mathrm{~kg}^{-1}$ oil, for the moringa oil by mechanical pressing, by extraction solvent and mixed crude oil, respectively, and correlates to the high acidity indexes mentioned earlier. This index was evaluated comparing the crude oils of moringa with the refined soybean oil $\left(0.5 \mathrm{meqO}_{2} \mathrm{~kg}^{-1}\right.$ oil - most used feedstock in Brazil to biodiesel and abundant use in food) and with an acceptable limit for edible crude oils (until 15 meqO $\mathrm{kg}^{-1}$ oil) and refined edible oils (until $10 \mathrm{meqO}_{2} \mathrm{~kg}^{-1}$ oil) by the ANVISA Resolution RDC n. 270/2005, for the product acceptability with low oxidative depreciation. The values obtained were above the reference for soybean, but within the acceptable limit for vegetable oils for biodiesel production or food, cosmetic or medicinal use (RDC n. 270/2005). The peroxide index for mixed purified oil was not detected with the methodology used indicating that the processes of degumming, neutralisation, washing and drying removed the contaminants that can cause oxidation (Pereira, 2015).

The water content of the method Karl Fischer (Tab. 2) were of $876.6 \mathrm{mg} \mathrm{kg}^{-1}$ for the moringa crude oil by mechanical pressing, $632.0 \mathrm{mg} \mathrm{kg}^{-1}$ by solvent extraction and $630.2 \mathrm{mg} \mathrm{kg}^{-1}$ for the mixed oil purified. The results for the oil obtained by chemical extraction and for the purified oil were similar, suggesting that using a solvent treatment, neutralising reagents and heating improves the acceptable water levels of the material, though an intrinsic indication in the structure of the fatty material might maintain some residual. The values were below the acceptable for oil feedstock for biodiesel $\left(0.1 \%\right.$ maximum humidity or $\left.1,000 \mathrm{mg} \mathrm{kg}^{-1}\right)$ or for other uses
(Oliveira et al., 2012). The water present in the oils, even in small quantities, is a negative factor, favouring the hydrolysis reactions, oxidation and microbial degradation (Pereira, 2015).

The specific masses (Tab. 2) for the moringa oil were of 907.2 and $909.5 \mathrm{~kg} \mathrm{~m}^{-3}$ at $40{ }^{\circ} \mathrm{C}$, for oil by mechanical pressing or by solvent extraction, respectively. The values in the reference studies were between $880.9 \mathrm{~kg} \mathrm{~m}^{-3}$ (Tsaknis et al., 1999, for solvent extraction) and $909.9 \mathrm{~kg} \mathrm{~m}^{-3}$ (Pereira et al., 2010 , for mechanical pressing) at $40^{\circ} \mathrm{C}$, with a constant tendency of reduction when using extraction by solvent. The specific mass of the purified oil was of $907.0 \mathrm{~kg} \mathrm{~m}^{-3}$ at $40{ }^{\circ} \mathrm{C}$, remaining within the reference range. The experimental values show that the solvent and treatments used slightly reduce the specific mass of the oil, which can be explained through the removal of impurities scattered presents in the fatty structures of the glycerides (major components) (Pereira, 2015). The specific mass of the moringa crude or purified oil is lower than of the refined soybean oil $\left(913.8 \mathrm{~kg} \mathrm{~m}^{-3}\right.$, at $\left.40{ }^{\circ} \mathrm{C}\right)$, but are within the average for vegetable oils (Sing and Sing, 2010), with values that vary from $902.6 \mathrm{~kg} \mathrm{~m}^{-3}$ for peanuts to $940.6 \mathrm{~kg} \mathrm{~m}^{-3}$ for babassu), but slightly higher than the values found for diesel oil $\left(852 \mathrm{~kg} \mathrm{~m}^{3}\right)$ or hydrous ethanol $\left(809 \mathrm{~kg} \mathrm{~m}^{3}\right)$, according to Garcia (2002).

The kinematic viscosity in $\mathrm{mm}^{2} \mathrm{~s}^{-1}$ at $40{ }^{\circ} \mathrm{C}$, obtained in this study (Tab. 2) and in the references for the moringa oil (crude or purified) is higher than for the refined soybean oil $\left(32.6 \mathrm{~mm}^{2} \mathrm{~s}^{-1}\right.$ at $40^{\circ} \mathrm{C}$ ) used as a standard Brazilian reference for vegetable oil for biodiesel production. The results of the study were: $43.6,39.1$ and $41.7 \mathrm{~mm}^{2} \mathrm{~s}^{-1}$ (at $40{ }^{\circ} \mathrm{C}$ for crude oil by mechanical pressing, by solvent extraction and mixed purified, respectively), close to the results obtained by Pereira et al. (2010) and Santana et al. (2010): 49.16 and $37.87 \mathrm{~mm}^{2} \mathrm{~s}^{-1}$ (at $40{ }^{\circ} \mathrm{C}$ ), respectively for mechanical pressing and for with hexane extraction. It is important to highlight that the presence of small quantities of residual solvent can influence in the lowest viscosity result when compared to the one of pressing and also by the fact that the solvent removes soluble components in it (Pereira, 2015). Tsaknis et al., (1999), Lalas and Tsaknis (2002) and Rahman et al., (2009), using the extraction oil by hexane of the moringa seeds, obtained results varying from 45 to $57 \mathrm{~mm}^{2} \mathrm{~s}^{-1}$ (at $40{ }^{\circ} \mathrm{C}$ ), within the vegetable oil's expectations according to Singh and Singh (2010), which found $27.2 \mathrm{~mm}^{2} / \mathrm{s}$ for the linseed oil and $53.6 \mathrm{~mm}^{2} \mathrm{~s}^{-1}$ for the crambe oil, including $32.6 \mathrm{~mm}^{2} \mathrm{~s}^{-1}$ for the soybean oil, all measured at $38{ }^{\circ} \mathrm{C}$, well above $3.06 \mathrm{~mm}^{2} \mathrm{~s}^{-1}$ obtained for diesel oil at $40{ }^{\circ} \mathrm{C}$ (Garcia, 2002). The kinematic viscosity (at $40{ }^{\circ} \mathrm{C}$ ) of the moringa oil was of $43.6 \mathrm{~mm}^{2} \mathrm{~s}^{-1}$ (by mechanical pressing), $39.1 \mathrm{~mm}^{2} \mathrm{~s}^{-1}$ (by solvent extraction) and $41.7 \mathrm{~mm}^{2} \mathrm{~s}^{-1}$ (for the purified mixed oil), also influenced by solvents and treatments, with small reduction in this parameter. In similar way to the specific mass, the treatments increases this parameter in relation to the one obtained by solvent, and reduces in relation to the one obtained by pressing (Pereira, 2015).

The saponification index can work as a subsidy to calculate the molar masses of the oil by the conversion of constituent acilglycerols (major components) in soaps and dosage by difference, in acid base titration. Roughly speaking, an adulteration in the saponifiable oleaginous can be noticed, as the fatty distribution is usually the same in these materials, 
within fatty acids with 8 to 26 carbons in chain, with possibility of including saturated or unsaturated ones (Pereira, 2015). The results of the study (Tab. 2) of $180.6 \mathrm{mg}_{\mathrm{KOH}} \mathrm{g}^{-1}$ and $179.4 \mathrm{mg}_{\mathrm{KOH}} \mathrm{g}^{-1}$ for oil by pressing and by solvent converge to the average found in the references for the moringa oil (176.23 and $179.80 \mathrm{mg}_{\mathrm{KOH}} \mathrm{g}^{-1}$, Tsaknis et al., 1999, $181.58 \mathrm{mg}_{\mathrm{KOH}} \mathrm{g}^{-1}$, Pereira et al., 2010 and $185.56 \mathrm{mg}_{\mathrm{KOH}} \mathrm{g}^{-1}$, Santana et al., 2010) and within the classic interval (between 180 and $200 \mathrm{mg}_{\mathrm{KOH}} \mathrm{g}^{-1}$ ) for oleaginous vegetables or saponifiable animals, such as the soybean oil $\left(190.0 \mathrm{mg}_{\mathrm{KOH}} \mathrm{g}^{-1}\right.$ and beef tallow (195 $\mathrm{mg}_{\mathrm{KOH}} \mathrm{g}^{-1}$ ) (Campestre, 2015).

The iodine value is used to evaluate the structural characteristic in relation to the unsaturation of the glycerol esters chain of the oil. The results of the study (Tab. 2) were: $68.9 \mathrm{~g}_{\text {I2 }} 100 \mathrm{~g}^{-1}$ for pressing oil and $70.7 \mathrm{~g}_{\text {I2 }} 100 \mathrm{~g}^{-1}$ for oil by solvent. The results are similar to the ones in the references (66.66 and $66.83 \mathrm{~g}_{\mathrm{I} 2} 100 \mathrm{~g}^{-1}$, Tskanis et al., 1999, by pressing and by solvent extraction), (73.66 $\mathrm{g}_{\mathrm{I} 2} / 100 \mathrm{~g}$, Pereira et al., 2010) by pressing) and ( $85.71 \mathrm{~g}_{\mathrm{I} 2} 100 \mathrm{~g}_{\text {oil }}^{-1}$, Santana et al., 2010, by extraction solvent). The soybean oil has between 120 and $141 \mathrm{~g}_{\mathrm{I} 2} 100 \mathrm{~g}^{-1}$ and beef tallow between 33 and $47 \mathrm{~g}_{\mathrm{I} 2} 100 \mathrm{~g}^{-1}$ (Campestre, 2015). The higher this index, the more unsaturated and vulnerable to oxidative degradation the fatty material will be. It is recommended to evaluate the iodine value in the crude oil to avoid interferences of substances or conditions that can change the characteristics and analytical results (Pereira, 2015).

The turbidity, an analytic parameter not very common in studies regarding oleaginous, served to evaluate the changes in appearance of the crude moringa oils during the degumming, neutralization, washing and drying (Pereira, 2015). The results of the study (Tab. 2) were of 64.1 NTU (by mechanical pressing oil), 12.6 NTU (for crude oil by solvent extraction), 18.7 NTU (for the mixed crude oil) and 2.1 NTU (for the mixed purified oil) and show that the chemical interaction with substances (extraction solvent or treatment reagents) promote the substantial reduction of turbidity caused by chemical species with no interest in the final composition of the purified oil, mainly if for biodiesel feedstock use (Pereira, 2015).

The parameters of content of humidity (present water), ash content and higher (HCV) or lower (LCV) calorific value are fundamental in any previous analysis of the possible use of biomass as an energetic source or as renewable fuel (Pereira et al., 2009). The humidity contributes negatively to this calorific value or to the energy stored in fuels. The ashes also contribute negatively when a possible amount of waste that can generate the burning of the biomass studied is considered (Garcia, 2002; Nogueira and Lora, 2003). From the point of view of energy per $\mathrm{kg}$ of fuel, the moringa oil can be used for direct burning, for the analysis of the result of the higher calorific values between $39.4 \mathrm{MJ} \mathrm{kg}^{-1}$ for the mixed purified oil and $40.3 \mathrm{MJ} \mathrm{kg}^{-1}$ for the crude pressing oil (Tab. 2), even lower than the $46.65 \mathrm{MJ} \mathrm{kg}^{-1}$ for diesel mineral oil (Garcia, 2002), but with less environmental impact, for being renewable and practically without sulphur. The ash contents (maximum of $5 \%$ ) and water value (maximum of 20\%) (Garcia, 2002; Nogueira and Lora, 2003) were well below the acceptable for biomass fuels, with the moringa oil with $0.09 \%$ and $0.06 \%$ for the crude oils and $0.007 \%$ for the purified oils (calculated based on water content by the Karl Fischer), while for the ash content were of $0.05 \%, 0.05 \%$ and $0.007 \%$, respectively.

\section{Conclusions}

The extractive yield of the moringa oil varied by between $11.36 \%$ (by pressing) and $36.48 \%$ (for hexane extraction), with an average of $23.92 \%$. The chromatographic profile of the fatty acids of the pressing oil was of $21.5 \%$ of saturated fatty acids and $78.5 \%$ of unsaturated, with predominance of the oleic acid (higher than $70 \%$ ). The moringa oils present an average calorific power of $37 \mathrm{MJ} \mathrm{kg}^{-1}$ and are considered good renewable fuels in direct burning. The gross moringa oil obtained by pressing shows pleasant sensory characteristics with fruity odor resembling nuts. The sensory appearance of the crude and purified oils is striking, with colours of the soft yellow for the orange. The purified moringa oil (degummed, neutralised, washed and dried) presents physicochemical characteristics interesting, mainly its viscosity $\left(41.7 \mathrm{~mm}^{2} \mathrm{~s}^{-1}\right.$ at $40{ }^{\circ} \mathrm{C}$ ) and acidity index $\left(0.2 \mathrm{mg}_{\mathrm{KOH}} \mathrm{g}^{-1}\right)$, with high potential for biodiesel feedstock or other use industrial as in cosmetic, food, medicinal and pharmaceutical. The results of the study wave the moringa as a plant with extraordinary properties, mainly in its oleaginous content and also for being an easily exploitable crop and technologies for their co-products easy to be conducted.

\section{Competing of interest}

The authors declare that they have no conflict of interest.

\section{References}

Abdulkarim SM, Long K, Lai OM, et al. 2005. Some physicochemical properties of Moringa oleifera seed oil extracted using solvent and aqueous enzymatic methods. Food Chem. 93: 25363.

ABNT. 2015. Associação Brasileira de Normas Técnicas. Normas diversas. Available from: http://www.abnt.org.br/normalizacao/ lista-de-publicacoes/abnt (last consult: 2015/20/12).

ANVISA. 2015. Agência Nacional de Vigilância Sanitária, Brasil. Resolução n²70/2005. Regulamento técnico para óleos vegetais e afins. Available from: http://portal.anvisa.gov.br/wps/wcm/ connect/82d8d2804a9b68849647d64600696f00/RDC_n_270. pdf?MOD=AJPERES (last consult: 2015/20/12).

Campestre Ind. e Com. Ltda. 2015. Especificações técnicas do óleo de soja e do sebo bovino. Available from: http://www.campestre. com.br/empresa.shtml (last consult: 2015/20/12).

Compaoré WR, Nikièma PA, Bassolé HIN, et al. 2011. Chemical Composition and Antioxidative Properties of Seeds of Moringa oleifera and Pulps of Parkia biglobosa and Adansonia digitata Commonly used in Food Fortification in Burkina Faso. Curr. Res. J. Biol. Sci. 3: 64-72.

Crosby GW. 2007. Soilless culture of moringa (Moringa oleifera Lam.) for the production of fresh biomass. (Doctoral Dissertation), University of Massachusetts Amherst.

Fahey JW. 2005. Moringa oleifera: A Review of the Medical Evidence for Its Nutritional, Therapeutic, and Prophylactic Properties. Part 1. Trees Life J. 1: 1-15. 
Foidl N, Makkar HPS, Becker, K. 2001. The potential of Moringa oleifera for agricultural and industrial uses. Available from: $\mathrm{http}: / /$ miracletrees.org/moringa-doc/the_potential_of_moringa_ oleifera_for_agricultural_and_industrial_uses.pdf (last consult: 2014/10/10).

Garcia R. Combustíveis e combustão industrial (1a. ed.), Rio de Janeiro, RJ: Interciência. 2002.

Hartman L, Lago RCA. 1973. Rapid preparation of fatty acid methyl esters from lipids. Laboratory Practice. 22, 475-476.

HDRA. 2002. The organic organisation. Moringa oleifera A Multi-purpose tree. Available from: http://miracletrees.org/ moringa-doc/all_about_moringa_the_wonder_tree.pdf (last consult: 2014/10/10).

IAL. 2008. Instituto Adolf Lutz. Métodos físico-químicos para análise de alimentos. (4nd. ed. - 1a. ed. dig.), São Paulo, SP: Editora do IAL. Available from: http://www.crq4.org. br/sms/files/file/analisedealimentosial_2008.pdf (last consult: 2014/10/10).

Jahn SAA. 1989. Proper Use Moringa Oleifera for Food and Water Purification - Selection of Clones and Growing of Annual ShortStem. Pflanzenzucht 4: 22-25.

Lalas S, Tsaknis J. 2002. Extraction and identification of natural antioxidant from the seeds of the Moringa oleifera tree variety of Malawi. J. Am. Oil Chem. Soc. 79: 677-683.

Morton JF. 1991. The horseradish tree, Moringa pterygosperma (Moringaceae) - a boon to arid lands? Economy Botany 45: 318 333.

Nogueira LAH, Lora EES. Dendroenergia: fundamentos e aplicações, 2nd edn. Rio de Janeiro: Interciência, 2003.

Oliveira DS, Fonseca XDS, Farias PN, et al. 2012. Obtenção do biodiesel através da transesterificação do óleo de Moringa oleifera Lam. HOLOS. 1: 49-61.
Pereira FSG. 2015. Viabilidade sustentável de biomassas de Moringa oleifera para produção de biodiesel e briquetes. (Tese de doutorado). Universidade Federal de Pernambuco - UFPE. Recife, PE, Brasil.

Pereira DF, Silva GP, Barreto MLG, Silva GF. 2010. Caracterização físico-química do óleo de moringa para possível rota de obtenção de biodiesel. In: IV Congresso Brasileiro de Mamona e I Simpósio Internacional de Oleaginosas Energéticas. João Pessoa, Brasil.

Pereira FSG, Drummond ARF, Coimbra G. 2009. Potencial energético de resíduos agrícolas do semiárido do Brasil. Biocombustiveis, potencialidades e restrições. BAHIA Análise $\mathcal{E}$ Dados. 18: 593-602.

Rahman IMM, Barua S, Nazimuddin M, et al. 2009. Physicochemical properties of Moringa oleifera lam. seed oil of the indigenouscultivar of Bangladesh. J. Food Lipids 16: 540-553.

Rashid U, Anwar F, Moser BR, Knothe G. 2008. Moringa oleifera oil: A possible source of biodiesel. Bioresour. Technol.. 99: 81758179.

Reda SY, Carneiro PIB. 2007. Óleos e gorduras: aplicações e implicações. Revista Analytica 27: 60-67.

Santana CR, Pereira DF, Araújo NA, et al. 2010. Caracterização físico-química da moringa (Moringa oleifera Lam). Revista Brasileira de Produtos Agroindustriais, Campina Grande 12: 5560.

Singh SP, Singh D. 2010. Biodiesel production through the use of different sources and characterization of oils and their esters as the substitute of diesel: A review. Renew. Sustain. Energy Rev. 14: 200-216.

Tsaknis J, Lalas S, Gergis V, et al. 1999. Characterization of Moringa oleifera Variety Mbololo Seed Oil of Kenya. J. Agric. Food Chem.. 47: 4495-4499.

Cite this article as: Francisco S.G. Pereira, Chesque C. Galvão, Valmir F. de Lima, Márcia F.A. da Rocha, Alexandre R.P. Schuler, Valdinete L. da Silva, Nelson M. de Lima Filho. The versatility of the Moringa oleifera oil in sustainable applications. OCL 2016, $23(6)$ A601. 